\title{
Napraforgó hibridek agronómiai tulajdonságainak összehasonlító vizsgálata a Hajuúságban
}

\author{
SZABÓ ANDRÁS \\ Debreceni Egyetem Agrár- és Gazdálkodástudományok Centruma \\ Növénytudományi Intézet, Debrecen
}

\begin{abstract}
Összefoglalás
A köztermesztésben szereplő korszerú napraforgó hibridek termésbiztonságának fokozása az agrotechnikai tényezők optimalizálását teszi szükségessé. A vetéstechnológia jelentôs mértékben képes kompenzálni az évjárat kedvezôtlen hatásait, valamint hozzájárulni a kórokozókkal szembeni sikeresebb védekezéshez és a termésmaximalizáláshoz. A tôszám és a vetésidő az agrotechnika két sarkalatos pontját képezi. A kísérletet a hajdúsági löszháton állítottuk be a 2009. évben. A köztermesztésben alkalmazott napraforgó hibridek tôszám és vetésidő reakcióját vizsgáltuk a kórtani tényezôk és a produktivitás vonatkozásában. Az eltérô időpontú vetésidők a szárszilárdsági paramétereket, valamint a betegségfertôzöttséget jelentôsen befolyásolták. A legkésôbbi idôpontú vetésidôben volt a szárdőlés és a tányér alatti szártörés mértéke a hibridek átlagában a legalacsonyabb (4,6\%, 1,9\%), míg a korai vetésidőben a legmagasabb (9,5\%, 6,3\%). Ugyanez a tendencia érvényesült a szár Sclerotinia, a Diaporte, valamint a tányérbetegségek fertôzöttségével kapcsolatban is. A tôszám növelése ugyancsak a szárszilárdsági paraméterek romlásához, valamint a vizsgált kórokozók infekciójának növekedéséhez vezetett. A 2009. száraz évjáratban az 55000 tố ha-1 állománysúrúség bizonyult optimálisnak ( 4838 kg/ha). A 2009. évben az április közepi vetésidôben kaptuk a hibridek átlagában a maximális termést ( $4717 \mathrm{~kg} / \mathrm{ha}$ ). A korábbi vagy későbbi vetésidő egyaránt terméscsökkenéshez vezetett ( $3712 \mathrm{~kg} / \mathrm{ha}, 4228 \mathrm{~kg} / \mathrm{ha}$ ). A kórokozók kártétele a vetésidő későbbre halasztásával fokozatosan csökkent. A hibridek olajtartalmát a vetésidó és az állománysưrúség befolyásolta. A legnagyobb átlagos olajtartalmat a 3. vetésidôben (44,51\%), valamint a legnagyobb vizsgált tôszámsűrúségi szinten figyeltük meg (44,27\%).
\end{abstract}


Az olajhozam alakulását elsôsorban a termésmennyiség határozta meg. A hibridek genotípusosan eltérô módon reagáltak a kísérlet során mind a tôszám, mind a vetésidô változására a vizsgált tényezőkkel kapcsolatban.

Kulcsszavak: napraforgó, vetésidő, tôszám, termés, olajtartalom

\title{
Comparative analysis of the agronomic traits of sunflower hybrids in the Hajdúság region
}

\author{
A. SZABÓ \\ University of Debrecen, Centre for Agricultural and Applied Economic Sciences, \\ Institute of Plant Sciences, Debrecen
}

\begin{abstract}
Summary
Increasing the yield safety of modern sunflower hybrids in common production makes it necessary to optimise agrotechnical factors. Sowing technology is able to significantly compensate the unfavourable effect of crop year, as well as to contribute to the more successful protection against pathogens and yield maximisation. Plant number and sowing date are two fundamental issues of agrotechnics. The experiment was established on the Hajdúság loess ridge in 2009. The plant number and sowing date reactions of the sunflower hybrids in common production were examined in relation to pathological factors and productivity. Different sowing dates significantly affected stem rigidity parameters and the level of infection. The extent of lodging and stem breakage under the head was the lowest at the latest sowing date in the average of hybrids ( $4.6 \%, 1.9 \%)$, whereas the highest values were observed in the case of the early sowing date $(9.5 \%$, $6.3 \%$ ). The same tendency prevailed in the case of stem Sclerotinia, Diaporthe and head disease infections. Furthermore, increasing plant number also led to worsening stem rigidity parameters and the increasing level of infection by the examined pathogens. In the dry crop year 2009, 55000 plant ha $^{-1}$ population density was shown to be optimal ( $4838 \mathrm{~kg} \mathrm{ha}^{-1}$ ). In 2009, maximum yield ( $4717 \mathrm{~kg} \mathrm{ha}^{-1}$ ) was obtained in the case of the mid-April sowing date in the average of hybrids. Both earlier or later sowing dates led to yield reduction (3712 $\left.\mathrm{kg} \mathrm{ha}^{-1}, 4228 \mathrm{~kg} \mathrm{ha}^{-1}\right)$. The damage caused by pathogens gradually decreased with later sowing dates. The oil content of hybrids was
\end{abstract}


affected by sowing date and population density. The highest average oil content was observed at the $3 \mathrm{rd}$ sowing date (44.51\%) and the highest examined plant density level (44.27\%). Oil yield was primarily determined by yield. Based on their different genotypes, hybrids reacted differently to the changes of both plant number and sowing date in relation to the examined factors during the experiment.

Key words: sunflower, sowing date, plant number, yield, oil content

\title{
Сравнительные исследования агрономических свойств гибридов подсолнечника в Хайдушаге
}

\author{
А. САБО \\ Институт Растениеводства Центра Агро-Экономических наук \\ Дебреценского Университета, Дебрецен
}

\begin{abstract}
Резюме
Увеличение надёжности урожая участвующих в общественном производстве современных гибридов подсолнечника делает необходимым оптимализацию агротехнических факторов. Посевная технология в значительной мере способна компенсировать неблагоприятные влияния года выращивания, а также содействует более успешной защите от возбудителей болезней и максимализации урожая. Число стеблей и время посева являются двумя основными моментами агротехники. Опыт проводили на хайдушагском лёссе в 2009 году. Исследовали реакцию числа стеблей и времени посева использованных в общественном производстве гибридов подсолнечника в отношении патологических факторов и продуктивности. Различные сроки посева значительно повлияли на параметры твёрдости стебля, а также на заражённость болезнями. При самом позднем сроке времени посева был самым низким размер наклона стеблей и ломки стеблей под тарелками в среднем у гибридов (4,6\%, 1,9\%), а при раннем времени посева - самым высоким (9,5\%, 6,3\%). Такая же тенденция проявилась при болезнях стебля Sclerotinia, Diaporte, а также в связи с заражённостью болезнями тарелки. Увеличение числа стеблей также привело к ухудшению параметров твёрдости стебля, и росту инфекции исследуемых возбудителей болезней. В сухом 2009 году плотность насаждения в 55000 стеблей/һа оказалась опти-
\end{abstract}


мальной (4838 kg/ha).В 2009 году при посеве в середине апреля получили в среднем у гибридов максимальный урожай $(4717 \mathrm{~kg} / \mathrm{ha})$. Более ранний или полее поздний срок посева в одинаковой степени привёл к уменьшению урожая (3712 kg/ha, 4228 kg/ha). Ущерб от возбудителей болезней с продвижением времени посева на более позднее постепенно уменьшился. Время посева и густота насаждения повлияли на содержание масла гибридов. Самое большое среднее содержание масла при 3-ем сроке посева $(44,51 \%)$, и при самом большом исследованном уровне густоты стеблей обнаружили (44,27\%). Формирование выхода масла прежде всего определяло количество урожая. Гибриды по генотипу различным образом реагировали на изменения числа стеблей и времени посева в ходе опыта в связи с исследуемыми факторами.

Ключевые слова: подсолнечник, время посева, число стеблей, урожай, содержание масла

\section{Bevezetés, irodalmi áttekintés}

A gabonafélék és a kukorica mellett a napraforgó a legnagyobb területen termesztett szántóföldi növényünk (Lehoczky és Sárkány 2006, Göksoy és Turan 2007, Szabó és Pepó 2007). Az agroökológiai feltételek a napraforgó számára Magyarországon kedvezóek (Dani és Pepó 2005). A klimatikus viszonyok az elmúlt idôszakban egyre szélsôségesebbé váltak (Mikulec és Stehlova 2006, Várallyay et al. 2007). A napraforgó hibridek termőképességére jelentős hatást gyakorolnak a különböző agrotechnikai (pl. tôszám, vetésidô), klimatikus és talajtényezôk az eltéró évjáratokban (Borbélyné és Lesznyák 2006, Zsombik 2006, Sándor et al. 2007). A napraforgó genotípusok agroökológiai és agrotechnikai igényei, valamint a stressztényezőkkel szembeni ellenállósága eltérô (Borbélyné et al. 2007).

A napraforgó nagyon jól képes adaptálódni a hazai éghajlati viszonyokhoz, termesztése Magyarországon jól megvalósítható. A megfelelő agrotechnika alkalmazása döntően befolyásolja a termesztés sikerességét. Az eltérô genotípusok és eltéró évjáratok átlagában, a hajdúsági csernozjom talajon átlagosan a 40 ezer db/ha körüli termôtôszámmal érték el a legkedvezőbb eredményeket. Az állománysúrúség növelése (45-55 ezer db/ha felett) költségnöveló és terméscsökkentố tényezô. (Pepó et al. 2002).

Az üzemi gyakorlatban sikeresen termeszthetô napraforgó hibrideknek a termésbiztonság, a termóképesség és termésminóség követelményeinek 
együttesen kell megfelelniük. E három tényezôcsoport közül - más növényektôl eltérôen - a termésbiztonság a legfontosabb tulajdonság. A napraforgó kedvezô adaptációs képessége folytán jól alkalmazkodik a szélsôséges évjárati viszonyokhoz (Bíró és Pepó 2008).

Pepó és Szabó (2005) az agrotechnikai tényezók hatását vizsgálták napraforgó állományokban, eltérő állománysưrưségnél (35 000-75000 tő/ha) a hajdúsági löszháton, csernozjom talajon 1999-2005 között. Az eredmények azt mutatták, hogy a csapadékosabb, hưvösebb évjáratban a napraforgó szár- és tányérbetegségek (diaporte, sclerotinia stb.) nagyobb arányú megjelenése miatt a terméseredmények kisebbek voltak. Az optimális állománysúrúség (45 00055000 tô/ha) hibridtôl függôen különbözött, ez azt bizonyította, hogy a csapadékos, húvös évjáratokban a hibridek szár- és tányérbetegség ellenállósága határozta meg az optimális állománysûrűséget. Szárazabb évjáratban kisebbek voltak a fertőzöttségi értékek a betegségek kisebb arányú terjedése miatt, ami a terméseredményekben és az olajhozamokban is megmutatkozott.

Aguilar et al. (2005) kísérleteik alapján megállapították, hogy az állománysûrûség növelésével noott a növények magassága, a levelek száma és a levélterületi index, továbbá növekedett a vízfelhasználás, a napfényenergia hasznosítása és a biomassza mennyisége.

A napraforgó hibridek eltéró tôszámreakcióval jellemezhetôk. Egyes hibridek a tôszámnövekedésre kisebb, míg más hibridek jelentôsebb terméstöbblettel reagálnak. Az eltérô genotípusú hibridek tôszámreakciója a különbözô években eltérhet egymástól. Száraz évjáratokban, amikor a betegségek fellépésére kisebb az esély, a napraforgó magasabb tőszámon adja a termésmaximumot, (meghaladhatja a 60-65 ezer db/ha tôszámot) (Lehoczky et al. 2002).

A napraforgó vegetációs ideje alatt különböző gyomnövények, növényi betegségek és károsító állatok jelenhetnek meg, és veszélyeztethetik a termés mennyiségét és minôségét (Lehoczky et al. 2006). A napraforgó termesztéstechnológiájának továbbfejlesztésében még inkább törekedni szükséges a biológiai alapok és termesztéstechnológiai elemek összehangolására, amit folyamatos kutatások nélkül hatékonyan megvalósítani nem lehet. Elsódleges célunk tehát ezeknek a tényezóknek a harmonizálása, a termésbiztonság, termésmennyiség és minóség fokozása az adott termóhelyi viszonyok között. 


\section{Anyag és módszer}

A kísérletet a Debreceni Egyetem Agrár- és Gazdálkodástudományok Centruma Látóképi Növénytermesztési Kísérleti Telepén végeztük. A kísérleti telep Debrecentől 15 km-re, a 33-as számú út mellett helyezkedik el a hajdúsági löszháton.

A kísérlet talaja löszön képződött, mély humuszrétegú alföldi mészlepedékes csernozjom talaj. A kísérleti terület talaja jó kultúrállapotú, középkötött (Arany-féle kötöttségi száma 43), talajfizikailag az agyagos-vályog kategóriába sorolható.

A termőréteg 80-90 cm vastagságú, amelyból 40-50 cm az egyenletesen humuszosodott réteg. Átlagos humusztartalom 2,76\%. $\mathrm{A} \mathrm{CaCO}_{3}$ a szelvényben az átmeneti szinten $75 \mathrm{~cm}$-es mélységben jelenik meg. A szénsavas mész általában lepedék formájában is látható a talajszemcséken, ebben a rétegben a mésztartalom 10-13\% között változik. A múvelt réteg pH-ja (KCl) 6,3-6,5 közötti értéket mutat.

Az össznitrogén a felsô 50 cm-es rétegben 0,12-0,15 \% között változik. Az össznitrogén tartalom alapján a terület N-ellátottsága közepesnek minôsíthetô.

Az ammónium-laktátos $\mathrm{P}_{2} \mathrm{O}_{5}$ és $\mathrm{K}_{2} \mathrm{O}$ tartalom meghatározás eredményeit elemezve megállapítható, hogy a kísérlet talajának káliumtartalma jó (240mg/kg). A foszforellátottság tekintetében a terület meglehetôs változékonyságot mutat. A minták átlagában a talaj közepes ellátottsággal jellemezhetô (133 mg/kg).

A kísérleti terület talajának vízháztartási jellemzőit vizsgálva megállapítható, hogy a csernozjom talajokra jellemző, kedvezô vízgazdálkodási tulajdonságokkal rendelkezik. A Várallyay-féle osztályozás szerint a IV. vízgazdálkodási kategóriába tartozik, azaz jó vízvezetési és víztartó tulajdonságokkal rendelkezik.

A minimális vízkapacitás $\left(\mathrm{VK}_{\min }\right)$ 34-46 térfogat\%, a holtvíztartalom (HV) 8,5-15,7 térfogat\% a 0-200 cm-es talajrétegben.

A talajvíz 8-10 m mélyen található, a talaj nagy mennyiségú csapadékvíz raktározására képes.

A kísérletet kézi vetőpuskával vetettük el, a tôszámok egzakt biztosítása céljából. A betakarítást speciális adapterrel felszerelt Sampo parcellakombájnnal végeztük el. Betakarításkor a parcellák nyers termését és nedvességtartalmát mértük. A terméseredményeket, olajtartalmat és olajhozamot 8\% nedvességtartalomra standardizáltuk. A vizsgálatokban 13 hibrid szerepelt. A kísérletben 
3 tényezôt vizsgáltunk (hibrid, tőszám, vetésidő). A kísérleti parcellákat véletlen blokk elrendezéssel, 4 ismétlésben állítottuk be. A parcellák mérete $15 \mathrm{~m}^{2}$ volt. A hibrideket 3 vetésidőben (1. vetésidô: 2009. március 29; 2. vetésidô: 2009. április 09:; 3. vetésidő: 2009. május 04.) és négy különbözô elméleti termôtőszámban állítottuk be (35-45-55-65 ezer tô/ha) 10000 tő/ha-os lépcsôben. A vizsgálatokban szereplő hibridek fenológiai, fenometriai, agronómiai, kórtani adatait négy ismétlésben felvételeztük.

\section{A 2009. tenyészév időjárásának alakulása}

2008. év októberében és novemberében lehullott csapadék mennyisége (16,1 mm, ill. 19,8 mm) lényegesen elmaradt a sokévi átlagtól (30,8 mm, ill. 45,2 mm). Az őszi hónapok átlaghőmérséklete (októberben $10,8^{\circ} \mathrm{C}$, novemberben $6,5^{\circ} \mathrm{C}$ ) meghaladta a sokévi átlagot $\left(10,3^{\circ} \mathrm{C}\right.$, ill. 4,5 $\left.{ }^{\circ} \mathrm{C}\right)$, amely elósegítette az evaporációt. Az átlagos csapadékú és átlagosnál melegebb időjárás a téli hónapokban is tovább folytatódott.

A 2009. év vegetációs periódus időjárásáról megállapíthatjuk, hogy a március hónap első felének időjárása meglehetôsen zord, télies volt, a hónap második felében már erôteljes felmelegedés kezdődött, melyet a talajhőmérsékleti értékek is bizonyítottak. Március hónapban lehullott csapadék mennyisége (41,6 mm) kismértékben meghaladta a sokévi átlagot $(33,5 \mathrm{~mm})$, a havi átlaghómérséklet $\left(5,4^{\circ} \mathrm{C}\right)$ pedig az átlaghoz hasonló $\left(5,0^{\circ} \mathrm{C}\right)$ volt az ellentétes hónap eleji és végi időjárás eredőjeként. Alapvető fordulat következett be a tavaszi idôjárásban áprilisban és májusban. Ezeket a hónapokat a rendkívüli szárazság és meleg időjárás jellemezte. Az áprilisban lehullott csapadék mennyisége (9,9 mm), valamint a májusi csapadék is $(20,1 \mathrm{~mm})$ csak töredéke volt a sokévi átlagnak (42,4 mm, ill. 58,8 mm). A májusi csapadék túlnyomó része a hónap utolsó napjaiban hullott. Ez gyakorlatilag két hónapos aszályos időjárást jelentett. Az április-májusi kevés csapadék kifejezett meleggel párosult. Áprilisban és májusban a havi átlaghômérséklet $\left(14,9^{\circ} \mathrm{C}\right.$, ill. $\left.17,4^{\circ} \mathrm{C}\right)$ több fokkal meghaladta a sokévi átlagot $\left(10,7^{\circ} \mathrm{C}\right.$, ill. 15,8 $\left.{ }^{\circ} \mathrm{C}\right)$. Átmenetileg jelentôsen enyhítette az állományok és a talaj vízhiányát a júniusi bôséges csapadék, amely meleg idôjárással párosult. Júniusban 96,6 mm csapadék hullott (a sokévi átlag 79,5 mm), a hômérséklet $\left(19,8^{\circ} \mathrm{C}\right)$ az átlagot $\left(18,9^{\circ} \mathrm{C}\right)$ kismértékben haladta meg. Júliusban $(9,2 \mathrm{~mm})$ és augusztusban $(11,3 \mathrm{~mm})$ gyakorlatilag elhanyagolható mennyiségú csapadék hullott (a sokévi átlag 65,7 mm, ill. 60,7 mm). A hômérsékleti 
értékek (júliusi havi átlag $23,4^{\circ} \mathrm{C}$, az augusztusi $22,6^{\circ} \mathrm{C}$ ) több fokkal meghaladták a sokévi átlagot $\left(20,3{ }^{\circ} \mathrm{C}\right.$, ill. $\left.19,6^{\circ} \mathrm{C}\right)(1-2$. táblázat). A napraforgó kitûnố szárazság és hôtûrésének köszönhetôen ez a rendkívüli idôjárás csak kevésbé viselte meg az állományokat. A nagy hasznos hőösszegek miatt a virágzás az átlagoshoz képest 1-1,5 héttel korábban kezdődött és relatíve gyors ütemben zajlódott le. A kánikulai, aszályos júliusi-augusztusi idôjárás kevésbé befolyásolta negatívan a virágzásbiológiai és termékenyülési folyamatokat, valamint a kaszattelítôdést. A meleg, száraz időjárás következtében a levél-, szárés tányérbetegségek relatíve késôn jelentek meg a napraforgó állományokban, terjedési dinamikájuk is relatíve mérsékelt volt Az állományok érése augusztus végén erôteljesen előrehaladt, szeptemberben azonban az érési folyamatok lelassultak az erôteljes éjszakai lehúlések és páraképzôdés miatt, így az állományokat szeptember közepén lehetett betakarítani (1-2. táblázat).

1. táblázat. A csapadékmennyiség alakulása a vizsgált tenyészévben (Debrecen-Látókép, 2008-2009)

\begin{tabular}{|c|c|c|c|c|c|c|c|c|c|c|c|}
\hline \multicolumn{12}{|c|}{$2008-2009(\mathrm{~mm})$} \\
\hline $\begin{array}{c}\text { Okt. } \\
(1)\end{array}$ & $\begin{array}{r}\text { Nov. } \\
(2) \\
\end{array}$ & $\begin{array}{c}\text { Dec. } \\
(3)\end{array}$ & $\begin{array}{r}\text { Jan. } \\
(4) \\
\end{array}$ & $\begin{array}{c}\text { Febr. } \\
(5)\end{array}$ & $\begin{array}{c}\text { Márc. } \\
\text { (6) }\end{array}$ & $\begin{array}{c}\text { Ápr. } \\
(7)\end{array}$ & $\begin{array}{r}\text { Máj. } \\
\text { (8) }\end{array}$ & $\begin{array}{r}\text { Jún. } \\
(9)\end{array}$ & $\begin{array}{l}\text { Júl. } \\
(10) \\
\end{array}$ & $\begin{array}{l}\text { Aug. } \\
\text { (11) }\end{array}$ & $\begin{array}{c}\text { Össz. } \\
\text { (12) }\end{array}$ \\
\hline 16,1 & 19,8 & 52,2 & 29,5 & 44 & 41,6 & 9,9 & 20,1 & 96,6 & 9,2 & 11,3 & \multirow[b]{2}{*}{350,3} \\
\hline \multicolumn{6}{|c|}{203,2} & \multicolumn{5}{|c|}{147,1} & \\
\hline
\end{tabular}

Table 1. The amount of rainfall in the examined growing season. (Debrecen-Látókép, 2008-2009). (1) October, (2) November, (3) December, (4) January, (5) February, (6) March, (7) April, (8) May, (9) June, (10) July, (11) August, (12) Total.

\section{2. táblázat. A hömérséklet alakulása a vizsgált tenyészévben}

(Debrecen-Látókép, 2009)

\begin{tabular}{ccc|cc|c}
\hline \multicolumn{7}{c}{$2009\left({ }^{\circ} \mathrm{C}\right)$} \\
\hline Ápr. & Máj. & Jún. & Júl. & Aug. & Átlag \\
$(1)$ & $(2)$ & $(3)$ & $(4)$ & $(5)$ & $(6)$ \\
\hline 14,9 & 17,4 & 19,8 & 23,4 & 22,6 & 19,6 \\
& & 19,6 & & & \\
& 17,4 & & \multicolumn{2}{c}{23,0} & \\
\hline
\end{tabular}

Table 2. Temperature during the examined growing season (Debrecen-Látókép, 2009). (1) April, (2) May, (3) June, (4) July, (5) August, (6) Average. 


\section{Eredmények értékelése}

A mai korszerú napraforgó hibridek realizálható termésmennyiségét és olajtartalmát több tényezó befolyásolja. A napraforgó éghajlatigénye eltér a Magyarországon domináns szántóföldi növényi kultúráktól. Erôteljes gyökérzete, jó aszálytưrố képessége, valamint jelentôs növénykórtani szenzitivitása következtében szárazabb évjáratokban várhatunk hibridjeinktôl kiemelkedô terméseredményeket. Mindezek mellett a hibridnek és termótájnak megfeleló vetéstechnológia alkalmazása - az évjárattól eltérôen befolyásolható módon a termésmaximalizálás leghatékonyabb eszköze lehet. Az állománysűrúség és a vetésidô hatása hibridenként eltérô módon, de jelentôsen befolyásolja a betakarított termésmennyiséget. A 2009. év idôjárását aszályos és erősen csapadékos periódusok váltakozásával jellemezhetjük. A napraforgó hibridek jól kompenzálták ezeket a hatásokat.

A vetésidô hatása a vizsgált napraforgó hibridek szárszilárdsági paramétereire

A napraforgó hibridek vetésideje jelentôs mértékben befolyásolja a gombás betegségek fertôzésének mértékét, ezáltal a szárszilárdsági paraméterek alakulását egyaránt (3-4. táblázat). A korai vetésidőben a hibridek szárdôlésének, valamint tányér alatti szártörésének nagysága a vizsgált vetésidôk közül szignifikánsan a legmagasabb volt. A vetésidô későbbre halasztásával a hibridek szárszilárdsági paraméterei javultak. Az átlagos szárdôlés mértéke a késői vetésidôben a korai vetésidőhöz képest 4,9\%-kal szignifikánsan csökkent (9,5\%, 4,6\%). Hasonló tendencia volt megfigyelhetô a tányér alatti szártörés esetében is. A késôi vetésidőben szignifikánsan 4,4\% volt a csökkenés. A legnagyobb szárdôlést az ES Primis és az Ollimi hibrideknél kaptuk a vetésidők átlagában $(13,3 \%, 13,9 \%)$ és a vizsgált vetésidôkben egyaránt. A legtöbb letört tányérú növényt a vetésidốk átlagában a Petunia és az Ollimi hibrideknél kaptuk $(6,8 \%, 8,4 \%)$. A legalacsonyabb átlagos szárdőlést a Petunia, NK Kondi, és az NK Sinfoni hibrideknél (4,2\%, 3,4\%, 4,4\%) észleltük. A legalacsonyabb átlagos tányér alatti szártörést az ES Artimis, NX 65001, valamint a DKF333 hibrideknél figyeltük meg. A hibridek szárszilárdsági paramétereinek alakulását az 3. táblázat mutatja. 
3. táblázat. A vetésidő hatása a vizsgált napraforgó hibridek szárszilárdsági paramétereire a 2009. tenyészévben (Debrecen-Látókép, 2009)

\begin{tabular}{|c|c|c|c|c|c|c|c|c|}
\hline \multirow{3}{*}{$\begin{array}{l}\text { Hibrid } \\
\text { (5) }\end{array}$} & \multicolumn{4}{|c|}{$\begin{array}{c}\text { Szárdôlés (\%) } \\
\text { (1) }\end{array}$} & \multicolumn{4}{|c|}{$\begin{array}{c}\text { Tányér alatti szártörés (\%) } \\
\text { (2) }\end{array}$} \\
\hline & \multicolumn{3}{|c|}{$\begin{array}{l}\text { Vetésidő } \\
\text { (3) }\end{array}$} & \multirow{2}{*}{$\begin{array}{l}\text { Átlag } \\
(4)\end{array}$} & \multicolumn{3}{|c|}{$\begin{array}{l}\text { Vetésidő } \\
\text { (3) }\end{array}$} & \multirow{2}{*}{$\begin{array}{l}\text { Átlag } \\
(4)\end{array}$} \\
\hline & 03.29. & 04.09. & 05.04. & & 03.29. & 04.09. & 05.04. & \\
\hline Petunia & 6,2 & 4,2 & 2,1 & 4,2 & 12,8 & 6,3 & 1,3 & 6,8 \\
\hline NK Kondi & 4,2 & 3,1 & 2,9 & 3,4 & 6,4 & 3,9 & 1,2 & 3,8 \\
\hline NK Neoma & 6,8 & 4,2 & 3,8 & 4,9 & 7,5 & 4,5 & 2,7 & 4,9 \\
\hline ES Primis & 18,6 & 12,6 & 8,6 & 13,3 & 4,2 & 3,4 & 2,1 & 3,2 \\
\hline ES Artimis & 6,9 & 4,2 & 3,4 & 4,8 & 3,7 & 2,1 & 1,1 & 2,3 \\
\hline Paraisol & 11 & 9,6 & 2,9 & 7,8 & 7,9 & 5,7 & 2 & 5,2 \\
\hline NX 65001 & 7,6 & 5,2 & 4,6 & 5,8 & 3,4 & 2,9 & 1,3 & 2,5 \\
\hline Ollimi & 16,4 & 14,6 & 10,8 & 13,9 & 11,9 & 8,3 & 5,1 & 8,4 \\
\hline NK Sinfoni & 7,3 & 3,2 & 2,7 & 4,4 & 6,2 & 4,7 & 2 & 4,3 \\
\hline NX 63732 & 8 & 5,4 & 4,2 & 5,9 & 4,5 & 2,3 & 1,3 & 2,7 \\
\hline DKF 3333 & 10,3 & 8,4 & 3,8 & 7,5 & 3,4 & 2,6 & 1,5 & 2,5 \\
\hline SF Acton & 11,7 & 6,7 & 3,6 & 7,3 & 5,2 & 3,1 & 1,2 & 3,2 \\
\hline PR 64H42 & 8,3 & 6,1 & 5,8 & 6,7 & 4,7 & 2,4 & 1,3 & 2,8 \\
\hline Átlag (4) & 9,5 & 6,7 & 4,6 & 6,9 & 6,3 & 4 & 1,9 & 4,1 \\
\hline $\mathrm{SzD}_{5 \%}(6)$ & 2,1 & 2,6 & 2,5 & & 1,9 & 2,1 & 0,8 & \\
\hline
\end{tabular}

Table 3. The effect of sowing date on the stem rigidity parameters of the examined sunflower hybrids in the 2009 growing season (Debrecen-Látókép, 2009). (1) Lodging (\%), (2) Stem breakage under the head (\%), (3) Sowing date, (4) Average, (5) Hybrid, (6) LSD $5 \%$.

A vetésidô hatása a vizsgált napraforgó hibridek szár-és tányérbetegség fertözöttségére

Eltérố vetésidốk alkalmazása a betegségek fertôzésének mértékét jelentôsen befolyásolták. A vizsgált hibrideknél a szár- és tányérbetegségek infekciója a vetésidôk időbeli kitolásával csökkent. A tányérbetegségek átlagos fertőzöttsége 23,1\%-ról (1. vetésidô) 6,0\%-ra csökkent (3. vetésidő). A szár Sclerotinia fertôzöttség mértékének csökkenése $2,2 \%$ volt, míg ugyanez az érték a Diaporte fertőzöttség esetében elérte a 20\%-ot (25\%-ról 5\%-ra csökkent a fertôzöttség). 
A csökkenés minden esetben szignifikáns volt. A tányérbetegségek esetében a legalacsonyabb átlagos fertôzöttséget az NK Kondi és az NX 63732 hibrideknél kaptuk $(9,0 \%, 10,5 \%)$. A legerôsebb volt a tányérbetegségek fertôzése a tôszámok átlagában az Ollimi és a PR 64H42 hibrideknél (22,0\%, 19,9\%). Magas szár Sclerotinia fertőzöttséget mértünk az NK Sinfoni, valamint a PR 64H42 hibrideknél (3,1\%, 3,0\%), azonban a Paraisol és az NK Neoma hibridek kiváló ellenállóságot mutattak a Sclerotinia Sclerotiorum-mal szemben a vetésidôk átlagában. A Paraisol és az SF Acton hibrideknél a Diaporthe Helianthi kórokozó nem tudott jelentôsebb mértékú kárt okozni (9\%, 11\%). A legerôsebb átlagos fertózöttség az ES Artimis (24\%), Ollimi (20\%), NK Kondi (20\%), valamint a Petunia (20\%) hibrideknél alakult ki (4. táblázat).

A tôszám hatása a vizsgált napraforgó hibridek szárszilárdsági paramétereire

A hibridek szárszilárdsági paraméterei a különbözô tôszámoknál jelentôs eltéréseket mutattak (5. táblázat). Kilenc hibrid szárdőlésének mértéke a hibridek átlagos szárdőlési értéke alatt maradt (6,3\%), és csak négy esetben haladta meg az átlagértéket. A legnagyobb szárdôlést a tôszámok átlagában a vizsgált hibridek esetében az ES Primis (10,6\%) és az Ollimi (11,4\%) hibrideknél kaptuk. A legalacsonyabb átlagos szárdólési értékeket az NK Sinfoni (3,0\%) és az NX 63732 (3,9\%) hibrideknél tapasztaltuk. A tányér alatti szártörés átlagos nagysága a Petunia (7,4\%) és az Ollimi hibrideknél volt jelentôsebb. A hibridek többségénél a törött tányérok aránya alacsony szinten maradt, nem érte el a 4\%-ot. A legkedvezóbb értékeket a PR 64H42 (1,9\%), az SF Acton (2,2\%) és az NX $63732(2,3)$ hibridek mutatták. Az állománysûrúség növelése a szárszilárdsági paraméterek romlását idézte elô.

A tốszám hatása a vizsgált napraforgó hibridek szár-és tányérbetegség fertôzöttségére

A tốszám növelése a Diaporte, a Sclerotinia és a tányérbetegségek kórtani nyomását egyaránt növelte (5. táblázat). A tányérbetegségek fertőzöttsége legnagyobb mértékben az Ollimi (22,1\%), a PR64H42 (19,9\%), és a Petunia (18,1\%) hibrideknél jelentkezett. A legkisebb értékeket az NX 63762 (8,1\%), és a NK Kondi hibrideknél mértük. A Sclerotinia fertôzöttséggel szemben a 
legérzékenyebbek az NK Simfoni (2,9\%) és a PR 64H62 (2,8\%) hibridek voltak. A legkisebb volt a kártétel a Paraisol (1,1\%), NK Kondi (1,4\%), SF Acton (1,5\%), és az NK Neoma (1,6\%) esetében.

4. táblázat. A vetésidô hatása a vizsgált napraforgó hibridek növénykórtani paramétereire a 2009. tenyészévben

(Debrecen-Látókép, 2009)

\begin{tabular}{|c|c|c|c|c|c|c|c|c|c|c|c|c|}
\hline \multirow{3}{*}{$\begin{array}{l}\text { Hibrid } \\
\text { (1) }\end{array}$} & \multicolumn{4}{|c|}{$\begin{array}{c}\text { Tányérbetegségek (\%) } \\
\text { (2) }\end{array}$} & \multicolumn{4}{|c|}{$\begin{array}{c}\text { Sclerotinia } \\
\text { fertőzöttség (\%) } \\
(3)\end{array}$} & \multicolumn{4}{|c|}{$\begin{array}{c}\text { Diaporte } \\
\text { fertôzöttség (\%) } \\
(4)\end{array}$} \\
\hline & \multicolumn{3}{|c|}{$\begin{array}{c}\text { Vetésidő } \\
\text { (5) }\end{array}$} & \multirow{2}{*}{ - Átl. } & \multicolumn{3}{|c|}{$\begin{array}{l}\text { Vetésidó } \\
\text { (5) }\end{array}$} & \multirow{2}{*}{$\begin{array}{l}\text { Átl. } \\
(6)\end{array}$} & \multicolumn{3}{|c|}{$\begin{array}{l}\text { Vetésidó } \\
\text { (5) }\end{array}$} & \multirow{2}{*}{$\begin{array}{l}\text { Átl } \\
\text { (6) }\end{array}$} \\
\hline & $\begin{array}{l}03 . \\
29 .\end{array}$ & $\begin{array}{l}04 . \\
09 .\end{array}$ & $\begin{array}{l}05 . \\
04 .\end{array}$ & & $\begin{array}{l}03 . \\
29 .\end{array}$ & $\begin{array}{l}04 . \\
09 .\end{array}$ & $\begin{array}{l}05 . \\
04 .\end{array}$ & & $\begin{array}{l}03 . \\
29 .\end{array}$ & $\begin{array}{l}04 . \\
09 .\end{array}$ & $\begin{array}{l}05 . \\
04 .\end{array}$ & \\
\hline Petunia & 26,2 & 17,2 & 3,2 & 15,5 & 3,5 & 2,4 & 0,6 & 2,2 & 39 & 18 & 4 & 20 \\
\hline NK Kondi & 15,4 & 9,2 & 2,4 & 9,0 & 2,8 & 1,5 & 0,8 & 1,7 & 34 & 22 & 3 & 20 \\
\hline NK Neoma & 21,9 & 12,6 & 8,7 & 14,4 & 2,1 & 1,4 & 0,5 & 1,3 & 22 & 12 & 6 & 13 \\
\hline ES Primis & 29,7 & 18,7 & 6,3 & 18,2 & 2,9 & 1,6 & 0,9 & 1,8 & 21 & 10 & 7 & 13 \\
\hline ES Artimis & 17,6 & 13,2 & 4,2 & 11,7 & 3,6 & 2,7 & 0,6 & 2,3 & 38 & 26 & 8 & 24 \\
\hline Paraisol & 21,0 & 14,0 & 2,3 & 12,4 & 2,1 & 1,2 & 0,5 & 1,3 & 14 & 11 & 2 & 9 \\
\hline NX 65001 & 26,8 & 16,5 & 7,9 & 17,1 & 2,9 & 1,7 & 0,6 & 1,7 & 19 & 12 & 4 & 12 \\
\hline Ollimi & 32,4 & 22,3 & 11,3 & 22,0 & 3,6 & 2,8 & 1,6 & 2,7 & 31 & 20 & 10 & 20 \\
\hline NK Sinfoni & 21,9 & 12,4 & 5,9 & 13,4 & 4,2 & 3,1 & 1,9 & 3,1 & 25 & 13 & 8 & 15 \\
\hline NX 63732 & 17,5 & 9,4 & 4,7 & 10,5 & 3,7 & 2,6 & 1,8 & 2,7 & 23 & 14 & 7 & 15 \\
\hline DKF 3333 & 18,2 & 10,6 & 4,2 & 11 & 2,9 & 1,9 & 0,7 & 1,8 & 21 & 13 & 3 & 12 \\
\hline SF Acton & 21,4 & 12,8 & 6,9 & 13,7 & 2,8 & 1,7 & 0,8 & 1,8 & 15 & 10 & 7 & 11 \\
\hline PR $64 \mathrm{H} 42$ & 30,7 & 19,3 & 9,6 & 19,9 & 4,5 & 3,1 & 1,5 & 3,0 & 34 & 16 & 8 & 19 \\
\hline Átlag (6) & 23,1 & 14,5 & 6,0 & 14,5 & 3,2 & 2,1 & 1,0 & 2,1 & 25 & 15 & 5 & 15 \\
\hline $\mathrm{SzD}_{5 \%}(7)$ & 6,1 & 5,4 & 2,9 & & 0,9 & 0,7 & 0,5 & & 9 & 6 & 3 & \\
\hline
\end{tabular}

Table 4. The effect of sowing date on the plant pathological parameters of the examined sunflower hybrids in the 2009 growing season (Debrecen-Látókép, 2009). (1) Hybrid, (2) Head diseases (\%), (3) Sclerotonia infection (\%), (4) Diaporthe infection (\%), (5) Sowing date, (6) Average, (7) $\mathrm{LSD}_{5 \%}$. 
A vizsgált hibridek Diaporthe Helianthi fertôzéssel szembeni érzékenysége genotípusosan eltérônek bizonyult. A legnagyobb fertôzöttséget az Ollimi (22\%), az Es Artimis (22\%), és az Es Petunia (18\%) hibrideknél figyeltük meg. A legellenállóbb hibridek az SF Acton (10\%), a DKF 3333 (12\%), az NK Neoma (13\%), az ES Primis (13\%) és a Paraisol (13\%) hibridek voltak.

5. táblázat. A növénykórtani és szárszilárdsági paraméterek alakulása a tôszámok átlagában a vizsgált hibrideknél a 2009. tenyészévben

(Debrecen-Látókép, 2009)

\begin{tabular}{lccccc}
\hline \multirow{1}{*}{\begin{tabular}{c} 
Hibrid \\
\multicolumn{1}{c}{$(1)$}
\end{tabular}} & $\begin{array}{c}\text { Szárdólés } \\
(2)\end{array}$ & $\begin{array}{c}\text { Tányér } \\
\text { alatti szárt. } \\
\text { (3) }\end{array}$ & $\begin{array}{c}\text { Tányér- } \\
\text { betegségek } \\
(4)\end{array}$ & $\begin{array}{c}\text { Sclerotinia } \\
(5)\end{array}$ & $\begin{array}{c}\text { Diaporte } \\
(6)\end{array}$ \\
\cline { 2 - 6 } a tôszámok átlagában \\
Petunia & 5,9 & 7,4 & 18,1 & 2,4 & 18 \\
NK Kondi & 5,8 & 3,5 & 9,5 & 1,4 & 14 \\
NK Neoma & 4,6 & 4,3 & 13,5 & 1,6 & 13 \\
ES Primis & 10,6 & 3,6 & 15,2 & 1,8 & 13 \\
ES Artimis & 6,2 & 2,7 & 13,8 & 2,4 & 22 \\
Paraisol & 8,5 & 4,1 & 11,5 & 1,1 & 13 \\
NK 65001 & 5,6 & 2,6 & 12,8 & 1,9 & 14 \\
Ollimi & 11,4 & 6,2 & 22,1 & 2,2 & 22 \\
NK Sinfoni & 3,0 & 3,9 & 12,7 & 2,9 & 15 \\
NX 63732 & 3,9 & 2,3 & 8,1 & 2,4 & 17 \\
DKF 3333 & 7,3 & 2,9 & 11,2 & 1,9 & 12 \\
SF Acton & 4,2 & 2,2 & 11,7 & 1,5 & 10 \\
PR 64 H 42 & 4,6 & 1,9 & 19,9 & 2,8 & 14 \\
Átlag (8) & 6,3 & 3,7 & 13,9 & 2,0 & 15,2 \\
SzD5\%(9) & 2,7 & 1,8 & 4,2 & 1,0 & 4,7 \\
\hline
\end{tabular}

Table 5. Plant pathological and stem rigidity parameters in the average of plant numbers in the case of the examined hybrids in the 2009 growing season (Debrecen-Látókép, 2009). (1) Hybrid, (2) Lodging, (3) Stem breakage under the head, (4) Head diseases, (5) Sclerotinia, (6) Diaporthe, (7) (\%) in the average of plant numbers, (8) Average, (9) LSD ${ }_{5 \%}$. 
A vetésidő hatása a vizsgált napraforgó hibridek termésmennyiségére

A napraforgó hibridek optimális vetésidejének megválasztása meghatározó mértékben hozzájárul a maximális termésmennyiség eléréséhez, valamint a kórtani tényezők kártételének csökkentéséhez (4. táblázat). A korai vetés esetén a kórokozók jelentôsebb mértékú megjelenésével és kártételével, és ennek következtében a szárszilárdság csökkenésével kell számolni. A kísérlet során a legkisebb mértékú fertôzöttséget, és a legjobb szárszilárdságot a 3. késôi vetésidő során tapasztaltuk. A vetésidő kísérlet minden vizsgált hibridje az átlagos vetésidőben érte el a legnagyobb termésmennyiséget. A legkiemelkedóbb termôképességú hibridek az NK Kondi ( $5221 \mathrm{~kg} / \mathrm{ha}$ ) és az NK Simfoni ( $4667 \mathrm{~kg} / \mathrm{ha}$ ) voltak (6. táblázat). A legnagyobb termésmennyiséget a hibridek átlagában statisztikailag igazoltan az átlagos vetésidőben kaptuk.

\section{A tốszám hatása a vizsgált napraforgó hibridek termésmennyiségére}

A napraforgó hibridek termésmennyiségét a tôszám szintén jelentôsen befolyásolta (7. táblázat). A hibridek az állománysưrűség növelésére eltérô módon reagáltak. A legnagyobb termésmennyiséget hibridektől függően 45000-6500 tő/ha tôszámnál értük el. Alacsony, 45000 tô/ha állománysúrúségi szinten kaptuk a legnagyobb termést az NK Neoma (4828 kg/ha), és az NX 63732 ( 4926 kg/ha) hibrideknél. Az ES Artimis (4326 kg/ha), a Paraisol (5270 kg/ha) és az Ollimi (4926 kg/ha) hibridek termôképessége 65000 tő/ha tôszámnál volt a legnagyobb. A többi vizsgált hibrid termóképessége 55000 tő/ha-nál érte el a termésmaximumot. A legnagyobb termőképességú hibridek az NK Kondi ( 5714 kg/ha), az SF Acton ( 4896 kg/ha) és a Paraisol (4832 kg/ha) hibridek voltak a tôszámok átlagában. A legkisebb termésmennyiséget az ES Artimis (3886 kg/ha) és a PR64H32 (3914 kg/ha) hibrideknél realizáltuk. A tôszám növelése a hibridek termőképességének csökkenését vonta maga után a növekvô kórtani nyomás következtében. A legkisebb termésmennyiséget 35000 tő/ha állománysû́rúségnél kaptuk.

A tôszámnövelés hatására a termés nagysága 55000 tô/ha tôszámig szignifikánsan növekedett ( $4213 \mathrm{~kg} /$ ha-ról $4838 \mathrm{~kg} /$ ha-ra), a további tôszámnövelés hatására azonban 65000 tő/ha tôszámnál kisebb mértékú termésdepresszió következett be $(4740 \mathrm{~kg} / \mathrm{ha})$. 
6. táblázat. A vetésidő hatása a vizsgált napraforgó hibridek termésmennyiségére

a 2009. tenyészévben

(Debrecen-Látókép, 2009)

\begin{tabular}{|c|c|c|c|c|}
\hline \multirow{4}{*}{$\begin{array}{l}\text { Hibrid } \\
\text { (1) }\end{array}$} & \multicolumn{3}{|c|}{$\begin{array}{l}\text { Vetésidő } \\
\text { (2) }\end{array}$} & \multirow{2}{*}{$\begin{array}{l}\text { Átlag } \\
(3)\end{array}$} \\
\hline & 03.29. & 04.09. & 05.04. & \\
\hline & \multirow{2}{*}{\multicolumn{4}{|c|}{$\begin{array}{c}\text { Kaszattermés (kg/ha) } \\
(4)\end{array}$}} \\
\hline & & & & \\
\hline Petunia & 3141 & 4592 & 4220 & 3984 \\
\hline NK Kondi & 4351 & 5896 & 5416 & 5221 \\
\hline NK Neoma & 3989 & 4408 & 3684 & 4027 \\
\hline ES Primis & 3972 & 4789 & 4507 & 4423 \\
\hline ES Artimis & 2903 & 3824 & 3664 & 3464 \\
\hline Paraisol & 3710 & 4967 & 4519 & 4399 \\
\hline NK 65001 & 3760 & 4730 & 4405 & 4298 \\
\hline Ollimi & 3150 & 4487 & 3506 & 3714 \\
\hline NK Sinfoni & 4563 & 4910 & 4528 & 4667 \\
\hline NX 63732 & 3907 & 4890 & 4153 & 4317 \\
\hline DKF 3333 & 4128 & 4743 & 4576 & 4482 \\
\hline SF Acton & 3693 & 4990 & 4260 & 4314 \\
\hline PR 64 H 42 & 2993 & 4090 & 3520 & 3534 \\
\hline $\mathrm{SzD}_{5 \%}(5)$ & 386 & 408 & 379 & \\
\hline Átlag (3) & 3712 & 4717 & 4228 & 4219 \\
\hline
\end{tabular}

Table 6. The effect of sowing date on the yield of the examined sunflower hybrids in the 2009 growing season (Debrecen-Látókép, 2009). (1) Hybrid, (2) Sowing date (3) Average, (4) Achene yield $\left(\mathrm{kg} \mathrm{ha}^{-1}\right),(5) \mathrm{LSD}_{5 \%}$.

A vetésidô hatása a vizsgált napraforgó hibridek olajtartalmára és olajhozamára

A napraforgó hibridek olajtartalma a vizsgált vetésidők esetében 40,5\% és 47,1\% között változott (8. táblázat). A legnagyobb átlagos olajtartalmat a 3. vetésidőben mértük (44,5\%), ami 1,2\%-kal haladta meg az elsô vetésidő átlagos olajtartamát (43,2\%). A legnagyobb olajtartalmú hibridek az NK Kondi (46,6\%), és az NK Sinfoni (46,2\%) voltak. A legalacsonyabb volt az olajtartalom az ES Artimis (41,7\%), és a PR 64H42 (41,9) hibrideknél. A legnagyobb olajtar- 
talmat kilenc hibridnél a 3. vetésidôben, míg három hibrid esetében a 2. vetésidôben kaptuk. Az olajhozamot elsôsorban a termésmennyiség határozta meg, az olajtartalom módosító tényezó volt. Az olajhozam a 2009. évben 1175-2771 $\mathrm{kg} / \mathrm{ha} \mathrm{között} \mathrm{változott.} \mathrm{Az} \mathrm{olajhozam} \mathrm{a} \mathrm{hibridek} \mathrm{többségénél} \mathrm{a} \mathrm{2.} \mathrm{vetésidőben}$ volt a legnagyabb (12 hibrid). A hibridek átlagában az olajhozam a 2 . vetésidôben $2082 \mathrm{~kg} / \mathrm{ha}$ volt, jelentôsen meghaladva az 1. és 3. vetésidő olajhozam értékeit (1610 kg/ha, $1886 \mathrm{~kg} / \mathrm{ha})$. A legnagyobb átlagos olajhozamot az NK Kondi és a NK Sinfoni hibridek ( $2435 \mathrm{~kg} / \mathrm{ha}, 2155 \mathrm{~kg} / \mathrm{ha}$ ), a legalacsonyabbat az ES Artimis és a PR 64H42 hibridek (1451 kg/ha,1482 kg/ha) adták.

7. táblázat. A tôszám hatása a vizsgált napraforgó hibridek termésmennyiségére a 2009. tenyészévben

(Debrecen-Látókép, 2009)

\begin{tabular}{|c|c|c|c|c|c|c|}
\hline \multirow{3}{*}{$\begin{array}{l}\text { Hibrid } \\
\text { (1) }\end{array}$} & \multicolumn{4}{|c|}{$\begin{array}{c}\text { Tôszám (tô/ha) } \\
\text { (2) }\end{array}$} & \multirow{3}{*}{$\begin{array}{l}\mathrm{SzD}_{5 \%} \\
(4)\end{array}$} & \multirow{3}{*}{$\begin{array}{l}\text { Átlag } \\
(5)\end{array}$} \\
\hline & 35000 & 45000 & 55000 & 65000 & & \\
\hline & \multicolumn{4}{|c|}{$\begin{array}{c}\text { Termés (kg/ha) } \\
\text { (3) }\end{array}$} & & \\
\hline Petunia & 4013 & 4515 & 4680 & 4587 & \multirow{14}{*}{310} & 4449 \\
\hline NK Kondi & 5451 & 5802 & 6045 & 5559 & & 5714 \\
\hline NK Neoma & 4430 & 4828 & 4430 & 4408 & & 4524 \\
\hline ES Primis & 4243 & 4671 & 4852 & 4770 & & 4634 \\
\hline ES Artimis & 3350 & 3889 & 3978 & 4326 & & 3886 \\
\hline Paraisol & 4055 & 4861 & 5140 & 5270 & & 4832 \\
\hline NK 65001 & 4441 & 4532 & 4990 & 4902 & & 4716 \\
\hline Ollimi & 3676 & 4230 & 4681 & 4926 & & 4378 \\
\hline NK Sinfoni & 4227 & 4803 & 4980 & 4836 & & 4712 \\
\hline NX 63732 & 4515 & 4926 & 4810 & 4702 & & 4738 \\
\hline DKF 3333 & 4120 & 4441 & 4959 & 4647 & & 4542 \\
\hline SF Acton & 4663 & 4814 & 5296 & 4811 & & 4896 \\
\hline PR 64 H 42 & 3586 & 4145 & 4050 & 3874 & & 3914 \\
\hline Átlag (5) & 4213 & 4651 & 4838 & 4740 & & 4610 \\
\hline $\mathrm{SzD}_{5 \%}(4)$ & 439 & 455 & 499 & 524 & & \\
\hline
\end{tabular}

Table 7. The effect of plant number on the yield of the examined sunflower hybrids in the 2009 growing season (Debrecen-Látókép, 2009). (1) Hybrid, (2) Plant number (plants per ha) (3) Yield $\left(\mathrm{kg} \mathrm{ha}^{-1}\right)$, (4) $\mathrm{LSD}_{5 \%}$, (5) Average. 
8. táblázat. A vetésidő hatása a vizsgált napraforgó hibridek olajtartalmára, valamint olajhozamára a 2009. tenyészévben

(Debrecen-Látókép, 2009)

\begin{tabular}{|c|c|c|c|c|c|c|c|c|}
\hline \multirow{3}{*}{$\begin{array}{l}\text { Hibrid } \\
\text { (1) }\end{array}$} & \multicolumn{4}{|c|}{$\begin{array}{c}\text { Olajtartalom (\%) } \\
(2)\end{array}$} & \multicolumn{4}{|c|}{$\begin{array}{c}\text { Olajhozam }(\mathrm{kg} / \mathrm{ha}) \\
\text { (3) }\end{array}$} \\
\hline & \multicolumn{3}{|c|}{$\begin{array}{l}\text { Vetésidô } \\
\text { (4) }\end{array}$} & \multirow{2}{*}{$\begin{array}{l}\text { Átlag } \\
(5)\end{array}$} & \multicolumn{3}{|c|}{$\begin{array}{l}\text { Vetésidô } \\
\text { (4) }\end{array}$} & \multirow{2}{*}{$\begin{array}{l}\text { Átlag } \\
(5)\end{array}$} \\
\hline & 03.29 . & 04.09. & 05.04 . & & 03.29. & 04.09. & 05.04 & \\
\hline Petunia & 45,6 & 45,4 & 45,2 & 45,4 & 1432 & 2083 & 1905 & 1807 \\
\hline NK Kondi & 45,6 & 47,0 & 47,1 & 46,6 & 1982 & 2771 & 2551 & 2435 \\
\hline NK Neoma & 46,0 & 46,4 & 45,2 & 45,8 & 1833 & 2043 & 1664 & 1847 \\
\hline ES Primis & 43,9 & 43,5 & 45,0 & 44,1 & 1745 & 2083 & 2028 & 1952 \\
\hline ES Artimis & 40,5 & 41,4 & 43,5 & 41,8 & 1175 & 1583 & 1594 & 1451 \\
\hline Paraisol & 42,1 & 44,3 & 44,5 & 43,7 & 1562 & 2201 & 2011 & 1925 \\
\hline NK 65001 & 41,4 & 41,7 & 44,1 & 42,4 & 1556 & 1972 & 1942 & 1824 \\
\hline Ollimi & 41,7 & 42,4 & 42,0 & 42,1 & 1314 & 1902 & 1473 & 1563 \\
\hline NK Sinfoni & 45,0 & 46,6 & 47,0 & 46,2 & 2051 & 2288 & 2126 & 2155 \\
\hline NX 63732 & 42,9 & 44,3 & 43,7 & 43,6 & 1676 & 2166 & 1814 & 1885 \\
\hline DFK 3333 & 41,8 & 42,5 & 42,2 & 42,1 & 1723 & 2016 & 1930 & 1890 \\
\hline SF Acton & 44,8 & 45,5 & 45,9 & 45,4 & 1655 & 2268 & 1955 & 1959 \\
\hline PR 64H42 & 41,1 & 41,3 & 43,4 & 41,9 & 1230 & 1689 & 1527 & 1482 \\
\hline Átlag (5) & 43,3 & 44,0 & 44,5 & 43,9 & 1610 & 2082 & 1886 & 1860 \\
\hline
\end{tabular}

Table 8 . The effect of sowing date on the oil content and oil yield of the examined sunflower hybrids in the 2009 growing season (Debrecen-Látókép, 2009). (1) Hybrid, (2) Oil content (\%) (3) Oil yield $\left(\mathrm{kg} \mathrm{ha}^{-1}\right)$, (4) Sowing date, (5) Average. 
A tôszám hatása a vizsgált napraforgó hibridek olajtartalmára és olajhozamára

A tôszámsû́rúség változása szintén olajtartalmat módosító tényezóként jelentkezik (9. táblázat). Az olajtartalom tíz hibridnél 65000 tô/ha állománysúrúségnél volt a legmagasabb, míg három hibrid esetében az 55000 tô/ha tôszám volt az optimális.

A hibridek átlagában a legnagyobb olajtartalmat 65000 tő/ha tôszámnál értük el (44,3\%). A legnagyobb volt az átlagos olajtartalom az NK Kondi (46,5\%), SF Acton (46,6\%), valamint az NK Neoma (45,88\%) hibrideknél. A leggyengébb hibrideknek pedig a DKF 3333 (40,0\%), és ES Artimis (40,6\%) bizonyultak a tôszámok átlagában.

Az olajhozam a tôszámkísérletben hat hibridnél 55000 tô/ha, öt hibridnél 65000 tô/ha, míg két hibrid esetében 45000 tô/ha tôszámnál volt a legnagyobb. A hibridek átlagában 55000 tô/ha tôszámnál volt az olajhozam maximális (2122 kg/ha). A legnagyobb olajhozamot az NK Kondi és az SF Acton hibridek adták (2657 kg/ha, $2281 \mathrm{~kg} / \mathrm{ha})$.

A tôszám és a vetésidô hatása a napraforgó hibridek termésmennyiségére, olajtartalmára és olajhozamára

A termésmennyiség, az olajtartalom és az olajhozam interaktív vizsgálata alapján megállapítható, hogy a hibridek átlagában a termésmennyiség 55 00065000 tô/ha tôszámoknál volt a legnagyobb ( $4838 \mathrm{~kg} / \mathrm{ha}, 4740 \mathrm{~kg} / \mathrm{ha}$ ), és a tôszámcsökkenés következtében egyaránt csökkent. Az átlagos olajtartalom az állománysûrúség növelés hatására 41,9\%-ról 44,2\%-ra emelkedett. A legnagyobb olajhozamot 55000 tô/ha-nál mértük (2122 kg/ha) (1. ábra).

A legnagyobb termésmennyiséget a hibridek átlagában statisztikailag igazoltan a 2. vetésidô adta. A korai és késôi vetésidőben egyaránt terméscsökkenés következett be. Az átlagos olajtartalom ezzel szemben a vetésidő későbbre tolásával növekedett (43,3\%-ról 44,5\%-ra). Az olajhozam hasonló tendenciát mutatott, mint a termésmennyiség (2. ábra). 
9. táblázat. A vetésidô hatása a vizsgált napraforgó hibridek olajtartalmára, valamint olajhozamára a 2009. tenyészévben

(Debrecen-Látókép, 2009)

\begin{tabular}{|c|c|c|c|c|c|}
\hline \multirow{3}{*}{ Hibrid (1) } & \multicolumn{5}{|c|}{ Olajtartalom (\%) (2) } \\
\hline & \multicolumn{5}{|c|}{ Tôszám (tô/ha)(4) } \\
\hline & 35000 & 45000 & 55000 & 65000 & Átlag (5) \\
\hline Petunia & 41,7 & 44,2 & 44,2 & 45,4 & 43,9 \\
\hline NK Kondi & 45,8 & 46,2 & 46,9 & 47,2 & 46,5 \\
\hline NK Neoma & 45,5 & 45,9 & 46,2 & 46,1 & 45,9 \\
\hline ES Primis & 40,8 & 43,2 & 43,9 & 44,2 & 43,1 \\
\hline ES Artimis & 38,7 & 39,2 & 41,4 & 43,0 & 40,6 \\
\hline Paraisol & 41,2 & 42,5 & 43,2 & 44,9 & 43,0 \\
\hline NK 65001 & 40,0 & 41,9 & 41,8 & 42,8 & 41,6 \\
\hline Ollimi & 40,8 & 41,1 & 41,4 & 42,7 & 41,5 \\
\hline NK Sinfoni & 44,1 & 45,4 & 45,3 & 45,9 & 45,1 \\
\hline NX 63732 & 42,4 & 43,2 & 43,1 & 43,3 & 43,0 \\
\hline DFK 3333 & 38,1 & 39,6 & 40,8 & 41,5 & 40,0 \\
\hline SF Acton & 44,8 & 46,6 & 47,6 & 47,2 & 46,6 \\
\hline PR 64H42 & 40,1 & 41,5 & 43,0 & 41,4 & 41,5 \\
\hline Átlag (5) & 41,8 & 43,1 & 43,8 & 44,3 & 43,2 \\
\hline \multirow{3}{*}{ Hibrid (1) } & \multicolumn{5}{|c|}{ Olajhozam (kg/ha) (3) } \\
\hline & \multicolumn{5}{|c|}{ Tôszám (tô/ha) (4) } \\
\hline & 35000 & 45000 & 55000 & 65000 & Átlag (5) \\
\hline Petunia & 1673 & 1996 & 2067 & 2083 & 1954 \\
\hline NK Kondi & 2497 & 2680 & 2832 & 2621 & 2657 \\
\hline NK Neoma & 2014 & 2214 & 2044 & 2030 & 2075 \\
\hline ES Primis & 1733 & 2018 & 2131 & 2109 & 1998 \\
\hline ES Artimis & 1297 & 1526 & 1648 & 1859 & 1582 \\
\hline Paraisol & 1672 & 2067 & 2221 & 2366 & 2081 \\
\hline NK 65001 & 1775 & 1899 & 2086 & 2100 & 1965 \\
\hline Ollimi & 1498 & 1737 & 1937 & 2104 & 1819 \\
\hline NK Sinfoni & 1862 & 2178 & 2256 & 2217 & 2128 \\
\hline NX 63732 & 1913 & 2128 & 2074 & 2038 & 2038 \\
\hline DFK 3333 & 1568 & 1760 & 2022 & 1929 & 1820 \\
\hline SF Acton & 2089 & 2241 & 2523 & 2271 & 2281 \\
\hline PR $64 \mathrm{H} 42$ & 1438 & 1721 & 1741 & 1602 & 1626 \\
\hline Átlag (5) & 1772 & 2013 & 2122 & 2102 & 2002 \\
\hline
\end{tabular}

Table 9. The effect of plant number on the oil content and oil yield of the examined sunflower hybrids in the 2009 growing season (Debrecen-Látókép, 2009). (1) Hybrid, (2) Oil content (\%) (3) Oil yield $\left(\mathrm{kg} \mathrm{ha}^{-1}\right)$, (4) Plant number (plants per ha), (5) Average. 
1. ábra. A tôszám hatása a vizsgált hibridek termésmennyiségére, olajtartalmára és olajhozamára a 2009. tenyészévben

(Debrecen-Látókép, 2009)

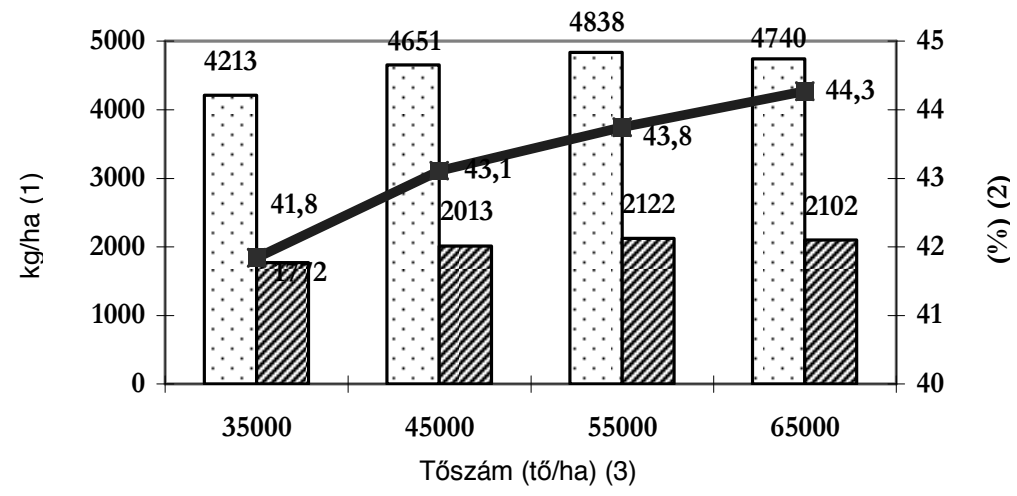

$\sqcap$ Termés (4) Olajtartalom (6)

Figure 1. The effect of plant number on the yield, oil content and oil yield of the examined hybrids in the 2009 growing season (Debrecen-Látókép, 2009). (1) (kg ha-1), (2) (\%), (3) Plant number (plants per ha), (4) Yield, (5) Oil yield, (6) Oil content.

2. ábra. A vetésidô hatása a vizsgált hibridek termésmennyiségére, olajtartalmára és olajhozamára a 2009. tenyészévben

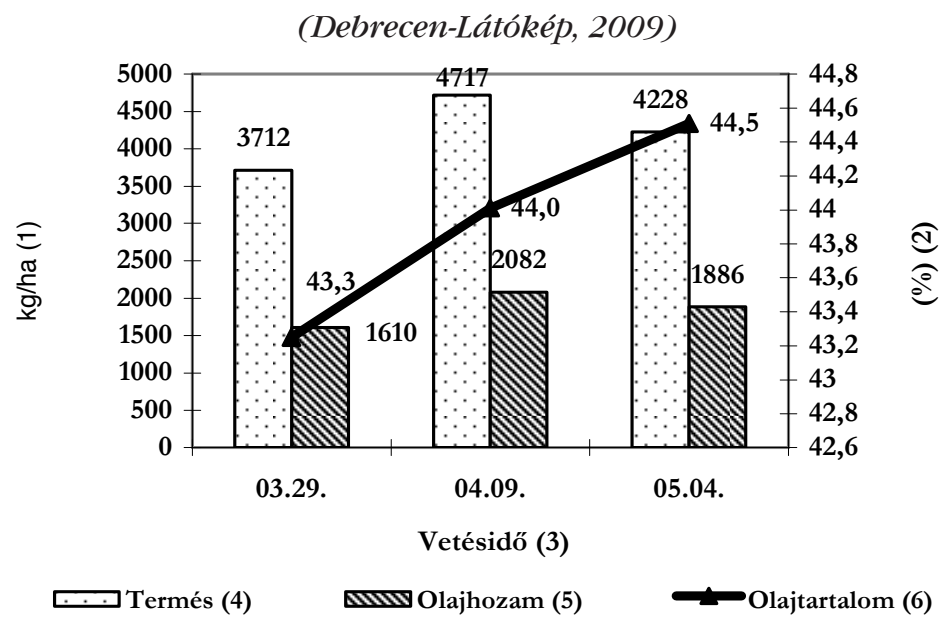

Figure 2. The effect of sowing date on the yield, oil content and oil yield of the examined hybrids in the 2009 growing season (Debrecen-Látókép, 2009). (1) $\left(\mathrm{kg} \mathrm{ha}^{-1}\right),(2)(\%)$, (3) Sowing date, (4) Yield, (5) Oil yield, (6) Oil content. 


\section{IRODALOM}

Aguilar, G. L.-Escalante, A.J. A.-Fucikovsky, Z. L.-Tijerina, C. L.-Engleman, E. M.: 2005. Leaf area, net assimilation rate, yield and plant density in sunflower. Terra. 23. 3: 303-310.

Birkás, M.-Dexter, A. R.-Kalmár, T.-Bottlik, L.: 2006. Soil quality-soil condition - production stability. Cereal Res. Commun. 34. 1: 135-138.

Bíró J.-Pepó P.: 2008. Néhány eltérô genotípusú napraforgó (Helianthus annuus L.) hibrid trágyareakciójának vizsgálata. Növénytermelés. 57. 2: 149-157.

Borbélyné Hunyadi, É.-Csajbók, J.-Lesznyák, M.: 2007. Relations between the yield of sunflower and the characteristics of the cropyear. Cereal Res. Commun. 35. 2: 285-288.

Borbélyné Hunyadi, É.-Lesznyák, M.: 2006. Investigating yield and phenological stages of sunflower varieties in agroecological enviroment. Cereal Res. Commun. 34. 1: 417-420.

Dani, M.-Pepó, P.: 2005. The yield potential utilization of some sunflower hybrids in different cropyears. Cereal Res. Commun. 33. 1: 193-196.

Göksoy, A. T.-Turan, Z. M.: 2007. Correlations and path analysis of yield components in synthetic varieties of sunflower (Helianthus annuus L.). Acta Agronomica Hungarica. 55. 3: 339-345.

Lehoczky, E.-Sárkány, E. Sz.: 2006. Influence of preemergence herbicides on the early growth of sunflower hybrids. Cereal Res. Commun. 34. 1: 1033-1036.

Lehoczky, É.-Pardi,J.-Szalai, T.-Dobozi, M.: 2002. Effect of pre-emergent herbicides on the growth of sunflower varieties. Zeitschrift für Pflanzenkrankheiten undPflanzenschutz. Sonderheft. 18: 937-941.

Lehoczky, E.-Reisinger, P.-Kömíves, T.-Szalai, T.: 2006. Study on the early competition between sunflower and weets in field experiments. Zeitschrift für Pflanzenkrankheiten undPflanzenschutz. Sonderheft, 20: 935-940.

Mikulec, V.-Stehlova, K.: 2006. Application of the climate change scenarios on selected meteorological charasterestics for the purposes of water content course prognosis in time horizons 2010, 2030 and 2075. Cereal Res. Commun. 34. 1: 45-48.

Pepó P.-Borbélyné Hunyadi É.-Zsombik L.: 2002. A napraforgó-termesztés agrotechnikai fejlesztési lehetôségei. Agrofórum. 13. 1: 19-22.

Pepó, P.-Szabó, A.: 2005. Effect of agrotechnical and meteorological factors on yield formation in sunflower production. Cereal Res. Commun. 33. 1: 49-52.

Sándor, Zs.-Kátai, J.-Tállai, M.-Varga, A.-Balogh, E.: 2007. The effect of herbicides applied in maize on the dynamics of some soil microbial groups and soil enzyme activity. Cereal Res. Commun. 35. 1: 1025-1028.

Szabó, A.- Pepó, P.: 2007. Effect of plant density on yield and oil content of different sunflower genotypes. Cereal Res. Commun. 35. 2: 1121-1124.

Várallyay Gy.-Láng I.-Csete L.-Jolánkai M. (szerk.): 2007. A globális klímaváltozás: hazai hatások és válaszok (A VAHAVA Jelentés). Agrokémia és Talajtan. 56. 1: 199-202. 
Zsombik, L.: 2006. Effect of sowing time on the oil content of different sunflower hybrids. Cereal Res. Commun. 34. 1: 725-728.

A szerzó levelezési címe - Address of the author:

Dr. Szabó András

Debreceni Egyetem AGTC

Növénytudományi Intézet

Debrecen

Böszörményi út 138.

$\mathrm{H}-4032$ 